\title{
Megalocytivirus infection in cultured Nile tilapia Oreochromis niloticus
}

\author{
Kuttichantran Subramaniam ${ }^{1, *}$, Michael Gotesman ${ }^{1}$, Charlie E. Smith ${ }^{2}$, \\ Natalie K. Steckler ${ }^{1}$, Karen L. Kelley ${ }^{3}$, Joseph M. Groff ${ }^{4}$, Thomas B. Waltzek ${ }^{1}$ \\ ${ }^{1}$ Department of Infectious Diseases and Pathology, College of Veterinary Medicine, University of Florida, Gainesville, \\ Florida 32611, USA \\ ${ }^{2} 715$ SE 5th St., College Place, Washington 99324, USA \\ ${ }^{3}$ Electron Microscopy Core, Interdisciplinary Center for Biotechnology Research, University of Florida, Gainesville, \\ Florida 32611, USA \\ ${ }^{4}$ School of Veterinary Medicine, University of California Davis, Davis, California 95616, USA
}

\begin{abstract}
Megalocytiviruses, such as infectious spleen and kidney necrosis virus (ISKNV), induce lethal systemic diseases in both ornamental and food fish species. In this study, we investigated an epizootic affecting Nile tilapia Oreochromis niloticus cultured in the US Midwest. Diseased fish displayed lethargy, gill pallor, and distension of the coelomic cavity due to ascites. Histopathological examination revealed a severe systemic abundance of intravascular megalocytes that were especially prominent in the gills, kidney, spleen, liver, and intestinal submucosa. Transmission electron microscopic examination revealed abundant intracytoplasmic polygonal virions consistent with iridovirus infection. Comparison of the full-length major capsid protein nucleotide sequences from a recent outbreak with a remarkably similar case that occurred at the same facility many years earlier revealed that both epizootics were caused by ISKNV. A comparison of this case with previous reports suggests that ISKNV may represent a greater threat to tilapia aquaculture than previously realized.
\end{abstract}

KEY WORDS: Iridoviridae - Megalocytivirus - Infectious spleen and kidney necrosis virus · Aquaculture $\cdot$ Ornamental fish

\section{INTRODUCTION}

Aquaculture is among the fastest-growing food industries, with an average annual increase of $3.2 \%$ over the last 5 decades (FAO 2014). Global aquaculture production in 2012 yielded over 60 million $t$, with Nile tilapia Oreochromis niloticus constituting more than 3.1 million t (FAO 2016). Farming of tilapia varies from extensive (ponds or reservoirs) to intensive (cages, ponds, raceways) and indoor recirculating systems (Watanabe et al. 2002, El-Sayed 2006). Several Asian (China, India, Indonesia, Thailand, Vietnam), African (Egypt, Kenya, Malawi, Zimbabwe), and Latin American (Brazil, Columbia, Honduras, Mexico) countries have adopted cage aquaculture (El-Sayed 2006). In the USA, insulated indoor culture systems predominate in northern and midwestern states, while pond culture is more typical in warmer western and southeastern states (Watanabe et al. 2002). 
Although tilapia are considered relatively resistant to disease, they are susceptible to common aquatic pathogens (e.g. viruses, bacteria, fungi, water molds, parasites) when reared intensively. The primary microbial pathogens affecting cultivated tilapia include Gram-negative bacteria (Aeromonas hydrophila, Flavobacterium columnare, and Francisella noatunensis), Gram-positive bacteria (Streptococcus spp.), and water molds such as members of the family Saprolegniaceae (e.g. Achyla and Saprolgenia spp.; Plumb \& Hanson 2010). Despite the global culture of tilapia, few viruses have been described from tilapia, and none has proven to be a serious threat to the industry (El-Sayed 2006).

The first RNA virus discovered in tilapia was an aquabirnavirus isolated from apparently healthy Mozambique tilapia O. mossambicus cultured in Lukang, Taiwan (Hedrick et al. 1983). In 2007, a betanodavirus was detected by RT-PCR in Nile tilapia larvae following a mass mortality event at a western European fish farm (Bigarré et al. 2009), and Eyngor et al. (2014) isolated a novel RNA virus (tilapia lake virus) from wild tilapia and confirmed its pathogenicity via experimental infection in Nile tilapia.

The first DNA viruses discovered in tilapia were iridoviruses. Although the family Iridoviridae is composed of 5 genera, only members of the genera Megalocytivirus, Lymphocystivirus, and Ranavirus infect fish (Zhang \& Gui 2015). Paperna (1973) detected lymphocystis virus in tilapine and haplochromine cichlids from the Rift Valley Lakes Kitangiri and Victoria. A severe (100\% mortality) epizootic among Mozambique tilapia fry held in an Australian aquatic disease laboratory was tentatively attributed to a ranavirus, Bohle iridovirus (Ariel \& Owens 1997). The affected fish displayed evidence of neurologic disease that was described as 'spinning tilapia' syndrome. Smith et al. (1997) described an iridoviral-like infection in Nile tilapia fingerlings imported into Idaho from Florida that resulted in lethal systemic disease. A remarkably similar iridoviral-like infection was reported soon thereafter in Nile tilapia fingerlings imported into Canada from Florida (McGrogan et al. 1998). Finally, a novel herpesvirus, referred to as tilapia larvae encephalitis virus, has been detected in laboratory-reared blue tilapia larvae (Shlapobersky et al. 2010, Sinyakov et al. 2011). The affected fish displayed signs of neurologic disease (e.g. whirling) prior to death (Shlapobersky et al. 2010).

The species Infectious spleen and kidney necrosis virus (ISKNV) is the only formally accepted member of the genus Megalocytivirus. Megalocytiviruses have been studied extensively due to their ability to cause significant disease across a wide range of cultured freshwater and marine species (Kurita \& Nakajima 2012, Subramaniam et al. 2012). Here we describe the first case of megalocytivirus infection in cultured Nile tilapia fingerlings based on pathologic and genetic evidence.

\section{MATERIALS AND METHODS}

\section{Clinical history}

From November to December 2012, a Midwestern aquaculture tilapia facility experienced heavy mortalities (50-75\%) among fry in troughs (approximately 200 1) receiving single-pass, flow-through fresh water maintained at a constant water temperature of $15^{\circ} \mathrm{C}$. Although water quality testing and bacteriology were not conducted, increasing and decreasing water flow to the troughs did not significantly alter the course of the disease nor did a $10 \mathrm{~d}$ course of florfenicol (FFC) incorporated into the feed (15 mg FFC kg-1 body weight $\mathrm{d}^{-1}$ ). On 2 separate occasions (10 and 27 December), 10 and 28 fish, respectively, were submitted to the Rangen Diagnostic Laboratory (Hagerman, ID) for examination. Total length of the tilapia fry ranged from 3.6 to $7.5 \mathrm{~cm}$, and moribund fish from both groups displayed lethargy, branchial pallor, and distension of the coelomic cavity due to a clear ascitic coelomic fluid. Examination of wet-mount preparations from external and internal tissues did not reveal infectious agents or significant lesions.

\section{Histopathology}

Five fish from the first group and 16 from the second group were fixed in Davidson's fixative for $24 \mathrm{~h}$ and then transferred to $70 \%$ ethanol before being shipped to the Bozeman Fish Health Center in Bozeman, Montana, for routine histological processing (Humason 1979). The $3 \mu \mathrm{m}$ paraffin sections were deparaffinized, stained with hematoxylin and eosin, and examined by light microscopy.

\section{Transmission electron microscopy}

A section of the intestine with histopathological changes consistent with iridovirus infection was selected from a paraffin block and submitted to the 
Electron Microscopy Core, Interdisciplinary Center for Biotechnology Research, University of Florida. The tissue was excised from the paraffin block and placed in $100 \%$ xylene overnight. The deparaffinized tissue was rehydrated through a decreasing ethanol series, washed with water and buffer, and subsequently fixed in Trump's fixative (Electron Microscopy Sciences). The fixed tissue was processed with the aid of a Pelco BioWave Pro laboratory microwave (Ted Pella). The sample was washed in $0.1 \mathrm{M}$ sodium cacodylate $(\mathrm{pH} 7.24)$, post-fixed with $2 \% \mathrm{OsO}_{4}$, washed with water, and dehydrated in a graded ethanol series $(25,50,75,95,100 \%)$. The dehydrated tissue was infiltrated with 50 and $100 \%$ LR White resin (Electron Microscopy Sciences) in 3 repetitions followed by overnight incubation at $4^{\circ} \mathrm{C}$. Resin-embedded tissue was cured at $60^{\circ} \mathrm{C}$ for $48 \mathrm{~h}$. Semi-thick sections were prepared at $500 \mathrm{~nm}$ and stained with toluidine blue. Ultra-thin sections at 80 to $120 \mathrm{~nm}$ were collected on carbon-coated Formvar copper 100 mesh grids, post-stained with $2 \%$ aqueous uranyl acetate and Reynold's lead citrate. Sections were examined with a Hitachi H-7000 TEM (Hitachi High Technologies America), and digital images were acquired with a Veleta $2 \mathrm{k} \times 2 \mathrm{k}$ camera and iTEM software program (Olympus Soft-Imaging Solutions).

\section{DNA extraction, PCR amplification, cloning, sequencing, and BLASTN analysis}

DNA from the same block described above was extracted using a DNeasy Blood and Tissue Kit (Qiagen) according to the manufacturer's protocol for formalin-fixed paraffin-embedded tissues. DNA from archived unstained slides from the original iridovirus-like case in tilapia (Smith et al. 1997) that occurred at the same facility as the 2012 cases presented here was similarly extracted with the following modifications. Five unstained slides each containing a parasagittal section $(5 \mu \mathrm{m})$ of the affected tilapia fry were warmed in a slide drying oven for $20 \mathrm{~min}$ at $37^{\circ} \mathrm{C}$ to soften and facilitate the transfer of all 5 sections to a single microcentrifuge tube.

PCR amplification of the complete major capsid protein (MCP) gene sequence was performed using 14 primer pairs as described by Sriwanayos et al. (2013). Briefly, the $50 \mu \mathrm{l} \mathrm{PCR} \mathrm{mixtures} \mathrm{consisted} \mathrm{of}$ $0.25 \mu \mathrm{l}$ of Platinum Taq DNA Polymerase (Invitrogen), $5 \mu \mathrm{l}$ of $10 \times$ PCR buffer, $2.0 \mu \mathrm{l}$ of $50 \mathrm{mM} \mathrm{MgCl}_{2}$, $1.0 \mu \mathrm{l}$ of $10 \mathrm{mM}$ dNTPs, $2.5 \mu \mathrm{l}$ of $20 \mu \mathrm{M}$ forward and reverse primers, $33.75 \mu \mathrm{l}$ of molecular grade water, and $3 \mu \mathrm{l}$ of DNA template. The PCR reactions included an initial denaturation of $5 \mathrm{~min}$ at $94^{\circ} \mathrm{C}_{i}$ followed by 40 cycles of denaturation at $94^{\circ} \mathrm{C}$ for $30 \mathrm{~s}$, annealing at $50^{\circ} \mathrm{C}$ for $1 \mathrm{~min}$, extension at $72^{\circ} \mathrm{C}$ for $1 \mathrm{~min}$; and a final elongation step at $72^{\circ} \mathrm{C}$ for $5 \mathrm{~min}$.

The purified PCR amplicons were then cloned using a TOPO TA Cloning kit (Invitrogen) and One Shot TOP10 cells (Invitrogen). White colonies were screened by PCR using the M13 primers to assess transformation as described by the manufacturer. Colonies containing appropriately sized inserts were cultivated for plasmid purification using a QIAprep Spin Miniprep Kit (Qiagen). Purified plasmid was submitted to the University of Florida, Interdisciplinary Center for Biotechnology Research (ICBR) for Sanger sequencing on an ABI 3130 platform using M13 primers. Following primer removal, the overlapping sequences were assembled in CLC Genomics Workbench 7.5. A BLASTN search using the NCBI database (www.ncbi.nlm.nih.gov/blast/Blast.cgi) of the assembled full length MCP gene sequence was conducted to identify the viral agent.

\section{RESULTS}

\section{Histopathology}

Microscopic examination of parasagittal sections from the infected fish revealed disseminated anisocytotic megalocytes with highly enlarged cytoplasmic inclusions (Fig. 1) previously referred to as inclusionbody cells (Sudthongkong et al. 2002). Specifically, the cytoplasmic inclusions contained a flocculent or fine to coarse, granular, basophilic material or a dense, homogeneous, basophilic material. Occasional affected cells had enlarged hypochromatic nuclei often with exaggerated lobular nuclei or apparent multiple nuclei that contained a minimal abundance of clumped chromatin and 1 or 2 eosinophilic nucleoli that were considered an incipient change prior to the development of the cytological features previously mentioned (data not shown).

Megalocytic cells were especially abundant in the glomerular and intestinal lamina proprial capillaries, and the renal and splenic sinusoids, but also occurred within the ocular choroid rete mirabile and the branchial lamellar capillaries. Occasional megalocytes were attached or applied to the vascular endothelium or cardiac reticuloendothelium and partially invested by attenuated cells that were assumed to represent endothelial cells or reticuloendothelial cells, although the attenuated 


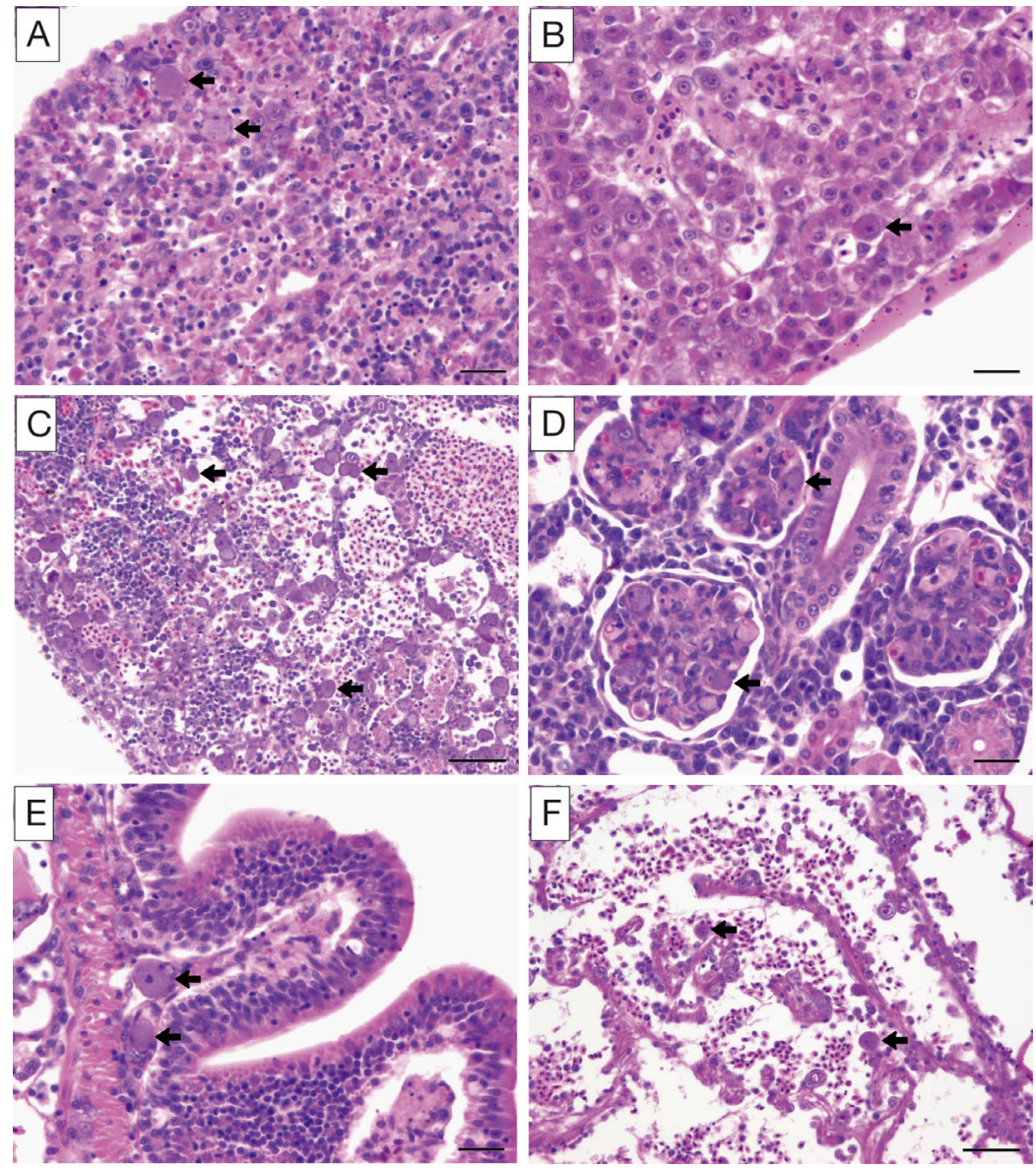

Fig. 1. Anisocytotic megalocytes with highly enlarged inclusions (arrows) in infected Nile tilapia Oreochromis niloticus. H\&E stain. (A) Spleen. (B) Liver. (C) Renal interstitium. (D) Renal glomeruli. (E) Intestinal submucosa. (F) Heart. Scale bars $=(\mathrm{A}, \mathrm{B}, \mathrm{D}, \mathrm{E}) 20 \mu \mathrm{m},(\mathrm{C}, \mathrm{F}) 50 \mu \mathrm{m}$ connective tissue cells, hepatocytes, and interrenal cells was considered less likely. The branchial lamellar and intestinal lamina proprial capillaries, and the renal and splenic sinusoids, often contained a variable abundance of an eosinophilic or yellow-brown to golden-brown material suggestive of cellular debris, although it could not be determined whether the material was secondary to degeneration and subsequent necrosis of the affected cells and/or erythrolysis and/or the accumulation of intravascular or intrasinusoidal fibrin as previously reported (Weber et al. 2009).

\section{Transmission electron microscopy}

Numerous polygonal viral particles consistent with an iridovirus were observed within the cytoplasm of enlarged intestinal submucosal cells (Fig. 2A). The mean ( \pm SD) diameter of the complete virions was $114 \pm 8 \mathrm{~nm}$ (n = 20) from opposite vertices and $105 \pm 7 \mathrm{~nm}(\mathrm{n}=20)$ from opposite faces. Viral particles were naked with an electron-dense nucleic acid core surrounded by a translucent zone and an outer nucleocapsid layer (Fig. 2B). cells may have also represented phagocytic cells or thrombocytes. Similar cells were present in the vascular spaces including the cardiac chambers, but not attached to the endothelium or reticuloendothelium. Rare or occasional affected cells were present in the gastric mucosal capillaries, hepatic vasculature, and hepatic sinusoids, and occasional hepatocytes had cytological changes that were suggestive of incipient transformation. Similar extravascular cells were present in the interrenal tissue, gastric serosa, and connective tissue including the periosseous connective tissue, but were not observed in the thymus.

The histogenesis of the affected cells could not be definitively determined, but the affected cells were primarily assumed to represent hematopoietic cells, although endothelial or reticuloendothelial cells may have also been involved. The non-hematopoietic or non-endothelial origin of the megalocytes such as

\section{Sequencing and BLASTN analysis}

The 14 PCR amplicons including the primers ranged in size from 121 to $214 \mathrm{bp}$, as previously described by Sriwanayos et al. (2013). After primer removal, the assembled sequencing products resulted in 1470 bp of contiguous viral genome containing the full-length iridoviral MCP gene sequence (1362 bp) for both the current (2012 case) and the archived material. The BLASTN searches for the MCP gene sequences (1362 bp) were $100 \%$ identical to each other and to the megalocytivirus, infectious spleen and kidney necrosis virus (ISKNV) previously reported from mandarinfish Siniperca chuatsi (GenBank Accession No. NC_003494). The ISKNV MCP sequences from the more recent case (2012) and the archived case (1997) were submitted to GenBank under accession numbers KU254554 and KU254555, respectively. 


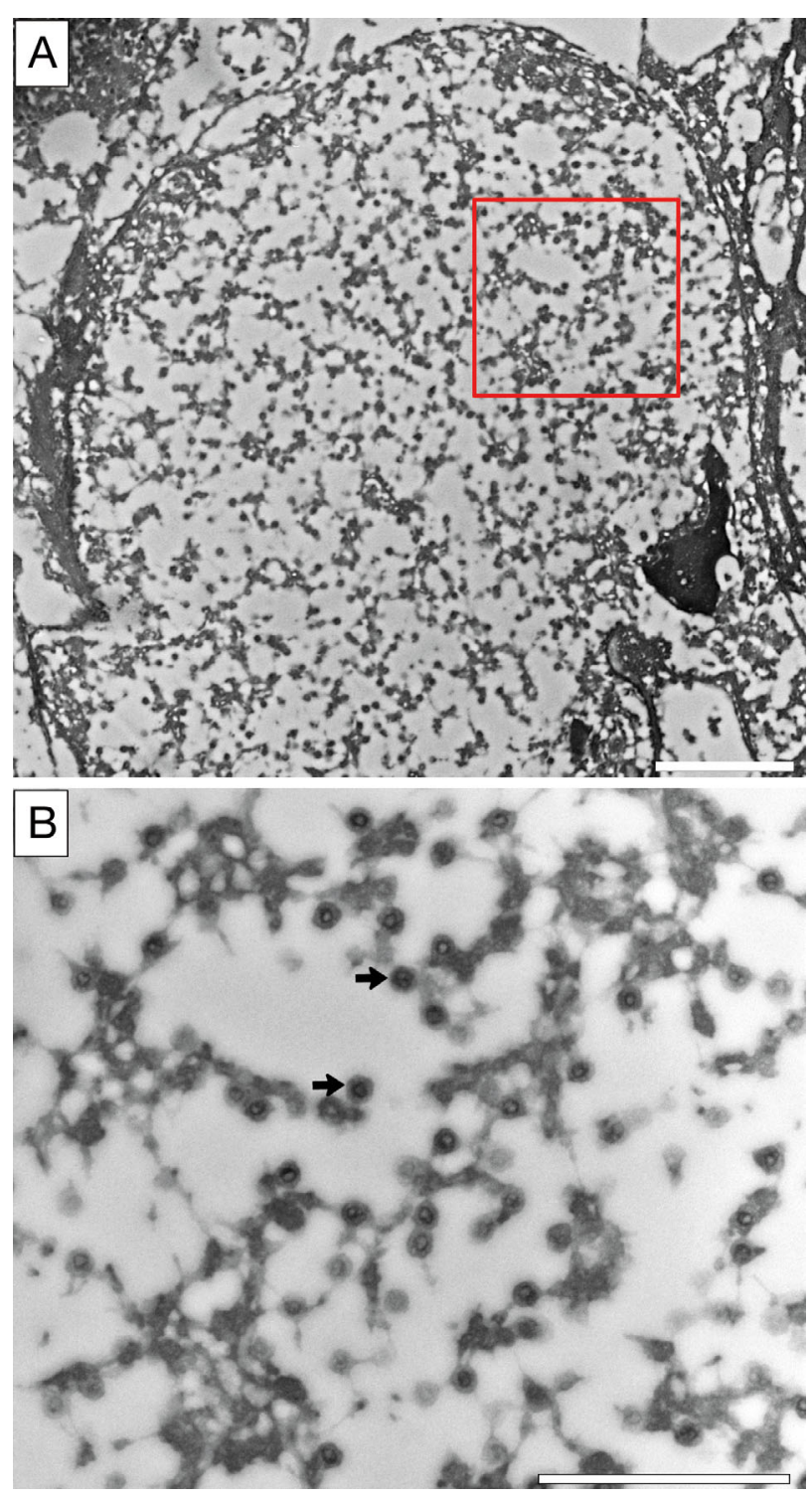

Fig. 2. Transmission electron photomicrographs of an iridovirus-infected intestinal submucosal cell of a Nile tilapia Oreochromis niloticus. (A) The infected cell is enlarged with rarefied cytoplasm containing numerous polygonal viral particles; red outlined area is enlarged in (B). Scale bar $=2 \mu \mathrm{m}$. (B) Higher magnification of naked icosahedral virions (arrows) with electron-dense nucleic acid core surrounded by a translucent zone and outer nucleocapsid layer. Scale bar $=1 \mu \mathrm{m}$

\section{DISCUSSION}

Previous studies described remarkably similar lethal iridoviral diseases in Nile tilapia following importation of fry from Florida (Smith et al. 1997, McGrogan et al. 1998). In agreement with our report, these studies characterized the systemic disease process as (1) affected fish displaying lethargy and coelomic distension due to ascites; (2) hypertrophic cells within the choroid of the eye, heart, intestinal submucosa, liver, hematopoietic tissues of the kidney/spleen, and other tissues; and (3) abundant cytoplasmic polygonal virions observed within enlarged cells. Disseminated hypertrophic cells or megalocytes with pronounced cytoplasmic inclusions are considered pathognomonic for members of the genus Megalocytivirus, including the type species ISKNV (Jancovich et al. 2012). However, our study provides the first genetic evidence that the iridovirus ISKNV was responsible for at least 2, and likely 3, lethal epizootics in cultured Nile tilapia (Smith et al. 1997, McGrogan et al. 1998).

Megalocytiviruses exhibit extremely low host specificity, with strains impacting both freshwater and marine finfishes reared for the ornamental and food fish industries. Strains such as red sea bream iridovirus and turbot reddish body iridovirus pose an important threat to Asian mariculture, impacting a wide range of Perciformes and a few Pleuronectiformes and Tetraodontiformes (Kurita \& Nakajima 2012, Subramaniam et al. 2012). In contrast, ISKNV has been associated with epizootics in a small number of freshwater food fishes, including mandarin fish, Murray cod Maccullochella peelii, marbled sleeper goby Oxyeleotris marmorata, and now Nile tilapia (He et al. 2000, Go \& Whittington 2006, Wang et al. 2011). However, ISKNV poses an important threat to freshwater ornamental aquaculture, impacting iconic groups such as gourami, tetras, livebearers, killifishes, and cichlids (Yanong \& Waltzek 2011, Nolan et al. 2015). In addition to Nile tilapia, ISKNV infects (1) other African cichlids such as kribensis Pelvicachromis pulcher and tropheus Tropheus dubosi; (2) the orange chromide Etroplus maculatus from Asia; and (3) South American cichlids including angelfish Pterophyllum scalare, oscar Astronotus ocellatus, ram Mikrogeophagus ramirezi, severum Heros seerus, flag cichlid Laetacara curviceps, and cockatoo dwarf cichlid Apistogramma cacatuoides. Most recently, ISKNV has been responsible for epizootics in marine ornamentals imported from Asia including the Bangaii cardinalfish Pteryapogon kaudernii (Weber et al. 2009) and orbiculate batfish Platax orbicularis (Sriwanayos et al. 2013).

Although the source of the virus in the current epizootic could not be determined, we now know the same facility previously experienced a nearly identical ISKNV outbreak following importation of Nile tilapia fry from Florida (Smith et al. 1997). Concurrent with the outbreak in 1997, the facility also experienced heavy mortalities in a freshwater ornamental species (angelfish) that displayed the same stereotypical 
Megalocytivirus microscopic pathology (C. E. Smith pers. obs.). A number of studies have demonstrated the ability of ISKNV to cross species boundaries. The ornamentally traded dwarf gourami Trichogaster lalius can transmit the dwarf gourami iridovirus (a strain of ISKNV) by cohabitation to the threatened Murray cod, revered as a sport and food fish within the Murray-Darling river system of southeastern Australia (Go \& Whittington 2006). Given the promiscuous nature of megalocytiviruses, the implementation of stringent biosecurity practices would seem prudent when rearing highly susceptible ornamental species (e.g. angelfish and gourami) alongside susceptible food fishes such as Nile tilapia (Schuh \& Shirley 1990, Rodger et al. 1997, Go \& Whittington 2006, Yanong \& Waltzek 2011, Nolan et al. 2015).

Acknowledgements. This study was partially funded by Florida Department of Agriculture and Consumer Services, Florida DACS Contract no. 021077. We thank R. N. Henriquez, S. A. Koda, and J. T. Freitas for their technical assistance throughout the study.

\section{LITERATURE CITED}

Ariel E, Owens L (1997) Epizootic mortalities in tilapia Oreochromis mossambicus. Dis Aquat Org 29:1-6

> Bigarré L, Cabon J, Baud M, Heimann M, Body A, Lieffrig F, Castric J (2009) Outbreak of a betanodavirus infection in tilapia, Oreochromis niloticus (L.), in fresh water. J Fish Dis 32:667-673

El-Sayed AFM (2006) Tilapia culture. CAB International, Wallingford

Eyngor M, Zamostiano R, Kembou Tsofack JE, Berkowitz A and others (2014) Identification of a novel RNA virus lethal to tilapia. J Clin Microbiol 52:4137-4146

FAO (2014) The State of World Fisheries and Aquaculture (SOFIA). FAO, Rome

FAO (2016) Cultured Aquatic Species Information Programme-Oreochromis niloticus (Linnaeus, 1758). www. fao.org/fishery/culturedspecies/Oreochromis_niloticus/en (accessed 15 Apr 2016)

Go J, Whittington R (2006) Experimental transmission and virulence of a Megalocytivirus (Family Iridoviridae) of dwarf gourami (Colisa lalia) from Asia in Murray cod (Maccullochella peelii peelii). Aust Aquacult 258:140-149

He JG, Wang SP, Zeng K, Huang ZJ, Chan SM (2000) Systemic disease caused by an iridovirus-like agent in cultured mandarinfish, Siniperca chuatsi (Basilewsky), in China. J Fish Dis 23:219-222

Hedrick RP, Fryer JL, Chen SN, Kou GH (1983) Characteristics of four birnaviruses isolated from fish in Taiwan. Fish Pathol 18:91-97

Humason GL (1979) Animal tissue techniques, 4th edn. WH Freeman, San Francisco, CA

Jancovich JK, Chinchar VG, Hyatt A, Miyazaki T, Williams T, Zhang QY (2012) Family Iridoviridae. In: King AMQ, Adams MJ, Carstens EB, Lefkowitz EJ (eds) Virus taxonomy: ninth report of the International Committee on
Taxonomy of Viruses. Elsevier Academic Press, San Diego, CA, p 193-210

Kurita J, Nakajima K (2012) Megalocytiviruses. Viruses 4: 521-538

> McGrogan DG, Ostland VE, Byrne PJ, Ferguson HW (1998) Systemic disease involving an iridovirus-like agent in cultured tilapia, Oreochromis niloticus L. - a case report. J Fish Dis 21:149-152

Nolan D, Stephens F, Crockford M, Jones JB, Snow M (2015) Detection and characterization of viruses of the genus Megalocytivirus in ornamental fish imported into an Australian border quarantine premises: an emerging risk to national biosecurity. J Fish Dis 38:187-195

Paperna I (1973) Lymphocystis in fish from East African lakes. J Wildl Dis 9:331-335

Plumb JA, Hanson LA (2010) Health maintenance and principal microbial diseases of cultured fishes. Wiley-Blackwell, Hoboken, NJ

Rodger HD, Kobs M, Macartney A, Frerichs GN (1997) Systemic iridovirus infection in freshwater angelfish, Pterophyllum scalare (Lichtenstein). J Fish Dis 20:69-72

Schuh JCL, Shirley IG (1990) Viral hematopoietic necrosis in an angelfish (Pterophyllum scalare). J Zoo Wildl Med 21: 95-98

> Shlapobersky M, Sinyakov MS, Katzenellenbogen M, Sarid R, Don J, Avtalion RR (2010) Viral encephalitis of tilapia larvae: primary characterization of a novel herpes-like virus. Virology 399:239-247

Sinyakov MS, Belotsky S, Shlapobersky M, Avtalion RR (2011) Vertical and horizontal transmission of tilapia larvae encephalitis virus: the bad and the ugly. Virology 410:228-233

Smith CE, Ramsey D, Speer CA, Blixt A (1997) Histopathology associated with an irido-like virus infection of tilapia. FHS/AFS Newsl 25:6-9

- Sriwanayos P, Francis-Floyd R, Stidworthy MF, Petty BD, Kelley K, Waltzek TB (2013) Megalocytivirus infection in orbiculate batfish Platax orbicularis. Dis Aquat Org 105: $1-8$

Subramaniam K, Shariff M, Omar AR, Hair-Bejo M (2012) Megalocytivirus infection in fish. Rev Aquacult 4:221-233

Sudthongkong C, Miyata M, Miyazaki T (2002) Iridovirus disease in two ornamental tropical freshwater fishes: African lampeye and dwarf gourami. Dis Aquat Org 48: 163-173

> Wang Q, Zeng WW, Li KB, Chang OQ and others (2011) Outbreaks of an iridovirus in marbled sleepy goby, Oxyeleotris marmoratus (Bleeker), cultured in southern China. J Fish Dis 34:399-402

Watanabe WO, Losordo TM, Fitzsimmons K, Hanley F (2002) Tilapia production systems in the Americas: technological advances, trends, and challenges. Rev Fish Sci 10:465-498

Weber ES III, Waltzek TB, Young DA, Twitchell EL and others (2009) Systemic iridovirus infection in the Banggai cardinalfish (Pterapogon kauderni Koumans 1933). J Vet Diagn Invest 21:306-320

Yanong RP, Waltzek TB (2011) Megalocytivirus infections in fish, with emphasis on ornamental species. Publication FA182. University of Florida, Institute of Food and Agricultural Sciences Extension, Gainesville, FL

Zhang QY, Gui JF (2015) Virus genomes and virus-host interactions in aquaculture animals. Sci China Life Sci 58:156-169 